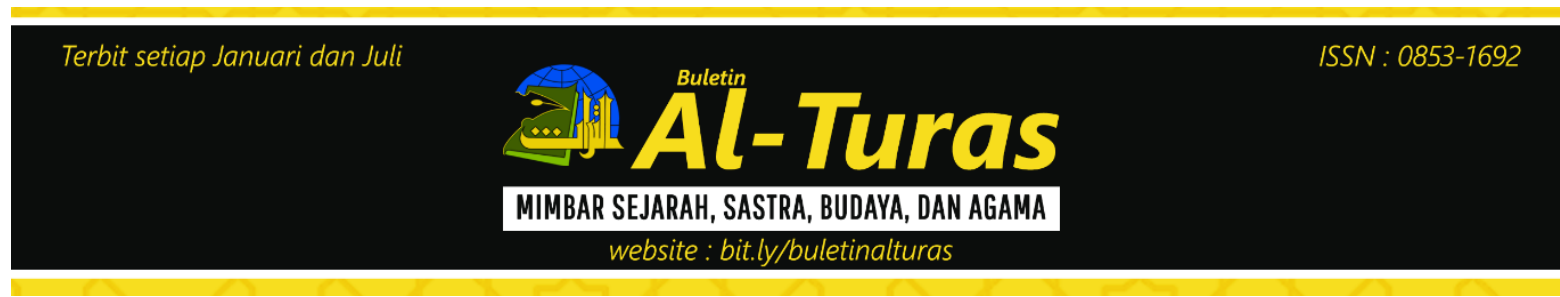

\title{
Media Komunikasi Sebagai Akses Layanan Referensi Virtual Di Perpustakaan Universitas Indonesia
}

\author{
Lailatur Rahmi \\ Lecturer Department of Library Science, Adab and Culture Science Faculty \\ UIN Imam Bonjol Padang
}

\begin{abstract}
The Reference Service is one of the library services designed to assist the users of the library in meeting their information needs. The development of reference services is, especially, important in the tertiary educational institutions. The growth of incredible information and technological developments decline the number of users of the printed reference collections; there are pros and cons when it comes to the technology that, supposedly, make things easier and practical. The study aims to describe the usefulness of communication media in virtual reference services at the University of Indonesia Library. The results of the study illustrate that the University of Indonesia library has provided communication media as access to virtual reference services through various communication media due to the influence of the development of technological sophistication
\end{abstract}

Keywords : Academic Libraries, Virtual Reference Service, Media Of Communication

\section{Abstraks}

Layanan referensi di Perpustakaan Universitas Indonesia merupakan salah satu layanan perpustakaan untuk mendukung perpustakaan menjalankan visi dan misi UI menuju Universitas Kelas Dunia. Era revolusi informasi membuat perpustakaan terus berusaha meningkatkan kualitas layanan yang diberikan kepada pemustaka. Perkembangan teknologi dan ilmu pengetahuan yang kita rasakan saat sekarang ini ternyata juga mempengaruhi perpustakaan terutama terhadap layanan perpustakaan termasuk pada layanan referensi. Penelitian bertujuan untuk menggambarkan ketergunaan media komunikasi dalam layanan referensi virtual di Perpustakaan Universitas Indonesia. Hasil penelitian menggambarkan bahwa perpustakaan Universitas Indonesia telah menyediakan media komunikasi sebagai akses layanan referensi secara virtual melalui berbagai media komunikasi karena pengaruh perkembangan kecanggihan teknologi.

Kata Kunci:Perpustakaan Perguruan Tinggi, Layanan Referensi Virtual, Media Komunikasi 


\section{A. Pendahuluan}

Latar Belakang

Virtual Reference Service merupakan salah satu pergeseran model yang lebih maju dari layanan referensi. Layanan ini dirancang untuk membantu pemustaka menggunakan media teknologi terutama ketika mereka tidak bisa hadir secara fisik ke perpustakaan. Menerima bentuk pelayanan melalui email, chatting, internet, software, telpon dan lainnya bertujuan membantu pemustaka dengan real time dalam memanfaatkan akses yang tersedia secara virtual. Layanan referensi virtual difokuskan untuk dapat menggapai pemustaka setiap saat ketika mereka ingin mengakses informasi.

Peningkatan layanan referensi virtual penting dilakukan terutama pada perpustakaan perguruan tinggi. Layanan yang bertujuan untuk berbagi informasi dari ruang yang luas, membuat teknologi memainkan peran yang penting sebagai saluran dalam telusur informasi. Pengguna bisa mengakses informasi dari desktop dan smart phones mereka. Pengguna juga bisa mengunduh ejournal, artikel, e-books dan informasi lainnya melalui media yang mereka punya ataupun yang disediakan perpustakaan. Layanan referensi virtual adalah layanan referensi yang dilakukan secara elektronik, di mana pelanggan menggunakan perangkat komputer dan teknologi lainnya untuk berkomunikasi dengan staf pustakawan referensi tanpa bertemu secara fisik (RUSA, 2010). ${ }^{1}$ Media atau saluran komunikasi yang sering digunakan dalam referensi virtual termasuk chatting, video conference, email, telephone, Voice over IP, cobrowsing, dan instant messaging (Gregory, 2009). 2 Dengan

\footnotetext{
1 Rusa. "Guide Reference Virtual Service" 2010 2 Gregory, Gwen. "Customizing Virtual Reference Tools for a Perfect Fit." Information Today, March 2009
}

menyuguhkan layanan referensi virtual ini maka perpustakaan dapat memperluas peningkatan layanan kepada komunitas pengguna tanpa dibatasi ruang dan waktu.

Layanan referensi virtual di perpustakaan akademik adalah komponen penting dari layanan perpustakaan yang mendapatkan persepsi positif dari pemustaka. Penelitian oleh Rawson, et al. (2013: 96) menemukan bahwa $92 \%$ dari pengguna menunjukkan bahwa layanan referensi virtual membantu dan $93 \%$ mengindikasikan bahwa mereka akan merekomendasikan hal ini kepada teman (Wagner, 2013). ${ }^{3}$ Penelitian ini bertujuan untuk membuat layanan referensi maya lebih menonjol bagi pengguna yang membutuhkannya.

Layanan referensi virtual akan lebih memuaskan pribadi pemustaka jika didukung oleh akses yang baik, sosok pustakawan yang berkompetensi dan didukung oleh teknologi sebagai media yang sesuai dengan kebutuhan pengguna. Hal penting yang sebenarnya harus disadari dalam lingkup layanan referensi virtual adalah ketanggapan pustakawan dalam menghadapi perkembangan media atau saluran komunikasi sebagai akses layanan bagi pengguna. Pada saat itulah pustakawan akan menerima lebih banyak permintaan informasi dari pemustaka secara online.

Layanan referensi di Perpustakaan Universitas Indonesia merupakan salah satu layanan perpustakaan untuk mendukung perpustakaan menjalankan visi dan misi UI menuju Universitas Kelas Dunia. Era revolusi informasi membuat perpustakaan terus berusaha meningkatkan kualitas layanan yang diberikan kepada pemustaka.

3 Wagner, M. Proprietary Reference: Do Students Use Library Help? The Reference Librarian. (2013). 54(3), 251-262. doi:10.1080/02763877.2013.770349 
Perkembangan teknologi dan ilmu pengetahuan yang kita rasakan saat sekarang ini ternyata juga mempengaruhi perpustakaan terutama terhadap layanan perpustakaan termasuk pada layanan referensi.

$$
\text { Layanan Referensi pada }
$$

perpustakaan UI sudah ada sejak berdirinya perpustakaan, membantu pengguna dalam hal penelusuran informasi, paket informasi, khususnya bagi mahasiswa yang sedang mengerjakan tugas akhir atau sedang melakukan penelitian. Pada perpustakaan UI, layanan referensi dengan penggunaan koleksi tercetak sudah jarang digunakan dan berpindah pada penelusuran informasi digital melalui internet. Penelusuran informasi digital diberikan dengan menyediakan online database dalam mendapatkan jurnal, artikel, dan buku dalam bentuk digital yang sudah dilanggan perpustakaan UI.

Fokus penelitian ini adalah untuk mengungkapkan bagaimana pustakawan mengaplikasikan media komunikasi yang telah ada di Perpustakaan sebagai akses layanan, sejauh mana media/saluran yang ada bisa bermanfaat bagi pustakawan dan mengungkapkan pemaknaan pustakawan akan penggunaan media atau saluran layanan referensi virtual yang telah disediakan oleh perpustakaan sebagai akses informasi.

\section{Metode}

Metode penelitian pada dasarnya merupakan cara ilmiah yang dipergunakan dalam penelitian sehingga memperoleh data dan informasi yang dibutuhkan. Menurut Sugiyono (2012:

\footnotetext{
4 Sugiyono. Metode Penelitian Kuantitatif, Kualitatif, dan Kombinasi (Mixed Methods).(Bandung: Alfabeta. 2012)

5 Arikunto, Suharsimi. Ed. Rev VI. Cet.

Ketigabelas. Prosedur Penelitian: suatu
}

3) "Metode penelitian adalah cara ilmiah untuk mendapatkan data dengan tujuan dan kegunaan tertentu". Metode dalam penelitian ini adalah metode deskriptif. Menurut Arikunto (2006:234) $)^{5}$, "Penelitian deskriptif tidak dimaksudkan untuk menguji hipotesis tertentu, tetapi hanya menggambarkan "apa adanya" tentang suatu variabel, gejala atau keadaan.

\section{B. Literature dan Pembahasan}

1. Layanan Referensi Virtual

Definisi secara bahasa dalam kamus Online Dictionary for Library and Information Science, 2014 adalah bahwa layanan referensi digital merupakan layanan yang diminta dan tersedia melalui internet, biasanya melalui e-mail, instant messaging (chatting) atau bentuk lain berbasis web. Layanan ini biasanya dijawab oleh pustakawan bagian referensi perpustakaan dan staff yang bergabung dalam bagian sejenis di Perpustakaan.

Menurut Machine Assisted Reference Section (MARS) dalam Pedoman penyelenggaran Layanan Referensi Virtual oleh RUSA, 2010 menyatakan bahwa:

"Virtual Reference is reference service initiated electronically often in realtime, where users employ computers or other Internet technology to communicate with librarians, without being physically present. Communication channels used frequently in virtual reference include chat videoconferencing, Voice over IP, e-mail and instant messaging. While online sources are often utilized in provision of virtual reference, use of

pendekatan praktek. (Jakarta: Rineka Cipta. 2006.)

${ }^{6}$ Rusa. "Guide Reference Virtual Service” 2010 
electronic sources in seeking answers is not of itself virtual reference. Virtual reference queries are often followed-up by telephone, fax, and regular e-mail, even though these modes of communication are not considered virtual"

Layanan referensi virtual dimulai secara elektronik dimana pengguna menggunakan komputer atau teknologi internet lainnya untuk berkomunikasi dengan pustakawan, tanpa hadir secara fisik ke Perpustakaan. Saluran komunikasi yang sering digunakan dalam referensi virtual termasuk chatting video conference, Voice over $I P$, e-mail dan pesan instan. Query Referensi Virtual sering ditindak lanjuti melalui telepon, fax, dan e-mail biasa, bahkan meskipun mode komunikasi ini tidak dianggap virtual.

Layanan referensi virtual menjadi layanan yang bisa dikatakan sangat penting karena bukan hanya manusia saja yang memediasi jasanya di perpustakaan, bahkan sudah sampai pada fungsi perpustakaan secara virtual. Layanan referensi virtual tampaknya akan menjadi layanan utama dalam meningkatkan nilai perpustakaan kedepan, karena senjata layanan referensi perpustakaan memiliki poin kuat dalam memberikan layanan tanpa batas tempat dan waktu.

Berube $(2003)^{7}$ menunjukkan bahwa layanan referensi virtual umumnya terdiri dari unsur-unsur berikut: pengguna, antar muka, sumber daya elektronik dan informasi professional.

1) Pengguna layanan: Seorang pengguna perpustakaan yang

\footnotetext{
${ }^{7}$ Berube, L. Digital reference overview. (An issue paper from the Networked Services Policy Task Group).( 2003). Retrieved http://www.ukoln.ac.uk/public/nsptg/virtual/
}

memiliki pertanyaan untuk bertanya, dll

2) Antarmuka: E-mail, formulir web, chatting, video conference, dll .;

3) sumber elektronik (termasuk sumber berbasis $\mathrm{CD}$, sumber daya web, materi digital lokal, sumber cetak, dll). Ini adalah sumber informasi di mana pustakawan akan mendapatkan jawaban.

4) Informasi yang profesional: Seorang agen pustakawan atau informasi yang akan mencari dan memberikan jawaban kepada pengguna;

Hoye, David $(2002)^{8}$ juga menambahkan bahwa dalam menyediakan akses publik secara virtual, maka perpustakaan akan menerima lebih banyak permintaan informasi online terumata melalui e-mail.

Layanan referensi virtual tidak bisa dianggap hanya sebagai layanan "ekstra" atau layanan tambahan yang hanya dikelola ketika staff cukup dan adanya ketersediaan waktu. Perencaan yang baik tidak hanya memastikan integrasi informasi akan tetapi juga memberikan waktu yang diperlukan untuk a) pelatihan staff, b) Orientasi pengguna, c) pengembangan penggunaan yang tepat dan perjanjian dalam peningkatan layanan, d) Identifikasi target pengguna, e) Evaluasi pengguna dan pemustaka.

\section{Tujuan Layanan Referensi Virtual}

Pelayanan referensi virtual tentu memiliki tujuan yang luar bisa dalam transformasinya dari bentuk yang

8 Hoye, David.Wired Life: Use of public libraries grows with Internet. (2002) Retrieval at http://www.sacbee.com/content/business/story/4 460123p-5480900c.html. 
konvensional. Menuru Maharana, B and Panda, K.C (2005) ${ }^{9}$ bahwa layanan referensi virtual memiliki tujuan dalam memenuhi kebutuhan pengguna baik yang datang ke perpustakaan maupun mereka yang mengakses dimanapun mereka berada melalui media yang telah disediakan. Tujuan dasar kemudian dijabarkan dalam beberapa point sebagai berikut:

a. memberikan layanan informasi perpustakaan bagi pengguna jarak jauh,

b. untuk meningkatkan dukungan perpustakaan dalam penelitian dan pendidikan,

c. untuk membantu pengumpulan sumber daya referensi virtual agar dikembangkan dan dipelihara,

d. untuk mencapai potensional pengguna agar terbiasa menggunakan media yang ada (to concert potential users to habitual users)

e. untuk memberikan bantuan kepada pengguna dalam mencari sumber informasi yang terbaik, lengkap dan valid

f. untuk membantu pengguna dalam pencarian online,

g. untuk menghemat waktu pengguna,

h. untuk memberikan layanan ini di berbagai negara sehingga layanan referensi virtual menjadi layanan publik

i. untuk memberikan program orientasi pengguna akan penggunaan akses

j. mengolah dan membuat hubungan yang lebih kuat dengan pengguna,

${ }^{9}$ Maharana, B. and Panda, K. C. Virtual Reference Service in Academic Libraries: A Case Study of the Libraries of IIMs and IITs in India. (2005). Availabe at k. untuk meningkatkan promosi dan pengiriman sumber daya perpustakaan serta layanan perpustakaan,

1. untuk membantu mencapai tujuan organisasi

m. memungkinkan untuk memenuhi lima hukum ilmu perpustakaan (to enable to fulfill the five laws of library science)

Berdasarkan uraian diatas dapat disimpulkan bahwa layanan referensi virtual bertujuan untuk memudahkan layanan pengguna tanpa batas waktu dan tempat. Mengarahkan pengguna menemukan sumber informasi yang mereka butuhkan, menyediakan saluran komunikasi dalam layanan sebagai akses secara virtual dan mengoptimalkan fungsi perpustakaan secara lebih efesien.

\section{Model Layanan Referensi Virtual}

Seiring perkembangan teknologi informasi, layanan referensi mengalami perkembangan dalam memberikan pelayanan seperti yang dikenal dengan referensi online, atau dikenal dengan istilah layanan referensi virtual, referensi elektronik, referensi maya, referensi digital, dan sebagainya. Layanan referensi virtual dimulai secara elektronik di mana pelanggan menggunakan komputer atau teknologi lain untuk berkomunikasi dengan staf pelayanan publik tanpa hadir secara fisik (RUSA, 2010:1).

Model layanan referensi virtual bisa dilihat dalam tiga kategori, bagan dibawah ini akan menunjukkan jenis layanan yang telah dipraktekkan di beberapa perpustakaan. 


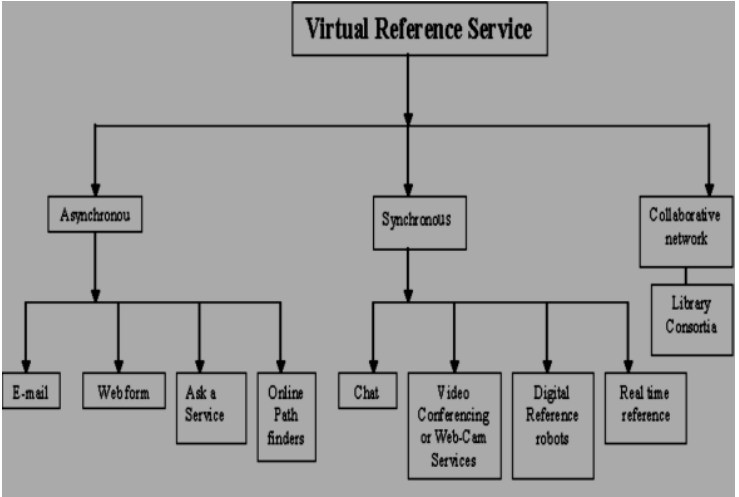

Topology of virtual Reference Service

(Sharma, Kumar and Singh, 2005:983) $)^{10}$

Figur di atas menunjukkan bahwa layanan referensi virtual terdiri dari:

a) Layanan Asynchronous

Layanan referensi virtual asynchronous adalah layanan yang ditandai dengan komunikasi satu arah pada satu waktu. Saluran komunikasi yang tersedia seperti $e$ mail, web form atau Ask a Service, Virtual Reference Desk, Question Point, Online Pathfinders, dan sejenisnya. Saluran ini dapat digunakan pemustaka untuk menanyakan tentang kebutuhan informasinya kepada pustakawan.

b) Layanan Synchronous

Adapun Layanan synchronous digambarkan sebagai 'real-time', dengan tanggapan langsung untuk query. Ini adalah komunikasi dua arah antara pengguna perpustakaan dan pustakawan melalui Internet. Media yang digunakan untuk komunikasi ini antara lain; chatting, instant messaging, layanan web cam dan Voice-Over Internet Protocol. Layanan sinkron komunikasi real time berlangsung antara pengguna perpustakaan dan pustakawan yang duduk di perpustakaan dengan

\footnotetext{
${ }^{11}$ Kern, Kathleen M. Virtual Reference Best Practice; tailoring service to
}

menggunakan teknologi interaktif. Pengguna perpustakaan melakukan komunikasi dengan mengklik sebuah tombol pada halaman web untuk bertukar pesan dengan pustakawan dan langsung mendapatkan umpan balik pada pertanyaan mereka.

c) Collaborative Network /

Layanan Kolaborasi

Kolaborasi referensi merupakan gabungan dari beberapa perpustakaan untuk menawarkan satu, dua atau lebih dalam menyediakan layanan referensi virtual untuk pelanggan mereka secara bersamaan. Layanan diberikan menggunakan internet dan media teknologi yang menghubungkan antara pustakawan dan pemustaka.

\section{Media Komunikasi Layanan Referensi Virtual}

Meninjau dari model layanan referensi virtual yaitu layanan asynchronous dan synchronous, maka berikut penjelasan mengenai media yang digunakan dalam setiap model. M.Kathleen Kern (2009) ${ }^{11}$ dalam bukunya Virtual Reference Best Practices bahwa tools yang dapat digunakan dalam layanan referensi virtual adalah:

1. Chat; Chatting dapat dilakukan dengan menggunakan berbagai jenis perangkat lunak, tetapi karakteristik yang membedakannya adalah "live" (real-time atau sinkron) dalam sifat komunikasi. Merupakan akses secara elektronik menggunakan jaringan dan komputer dengan teks yang ditransmisikan ke komputer.

your library. (United States of America: American Library Association. 2009). 
Chatting adalah komunikasi dua arah, sehingga pengirim akan dapat mengetik pesan kembali kepada penerima, begitupun sebaliknya secara cepat.

2. Instant Messaging

Instant messaging sangat mirip dengan chatting yaitu berbasis teks dan difasilitasi komputer. Perbedaannya adalah dalam perangkat lunak yang digunakan.

3. e- mail; e-mail adalah yang paling umum dan tertua dari alat komunikasi referensi virtual. Perpustakaan memilih menggunakan e-mail untuk layanan referensi selama lebih dari dua puluh tahun. Media ini memungkinkan pengguna untuk mengirim pesan setiap saat untuk seseorang yang mungkin atau tidak online pada waktu yang sama.

Pesan akan dibaca beberapa waktu kemudian setelah itu dikirim, sehingga dalam hal ini komunikasi $e$-mail mirip dengan surat yang ditulis di kertas.

4. Pesan Teks

Pesan teks adalah komunikasi melalui teks dari ponsel. Teks dapat diterima oleh pengguna dengan ponsel lain, atau dapat dikirim ke e-mail atau bahkan account. Kemudahan yang ditawarkan media memungkinkan pengguna dengan preferensi dan perangkat elektronik yang berbeda dalam mengirim dan menerima teks.

5. SMS; SMS, atau Short Message Service, adalah teks yang dapat dikirim dari ponsel digital. Protokol SMS membatasi panjang pesan individu untuk 160 karaktertermasuk spasi.

6. Vendor berbasis chat
Vendor berbasis chatting adalah istilah yang digunakan untuk membedakan antara referensi virtual yang menggunakan chat software, perangkat lunak dan jasa menggunakan IM.

8. Video Conferencing atau Video Chat

Video Chat termasuk transmisi video langsung dari setiap orang bersama dengan teks yang diketik. Hal ini dapat dikombinasikan dengan VoIP (Voice-over-InternetProtocol) sehingga baik gambar dan suara dikirim melalui komputer. Video Conferencing melebihi telepon tradisional yaitu dengan ditambah video, memerlukan peralatan yang agak unik dalam komunikasi.

\section{Perkembangan}

Layanan

\section{Referensi di Perpustakaan}

\section{Universitas Indonesia}

Perpustakaan Universitas Indonesia merupakan perpustakaan perguruan tinggi yang berada dalam lingkungan kampus Universitas Indonesia (UI). Pimpinan Universitas Indonesia pada tahun 1969 membentuk suatu Unit Pelaksana Teknis Perpustakaan Pusat dan semenjak saat itu perpustakaan pada tiap fakultas di lingkungan UI bernaung pada satu unit perpustakaan pusat. Pada tahun 1987 Universitas Indonesia menempati kampus baru di Depok, Jawa barat dan begitu juga dengan Perpustakaan pusat UI dengan gedung baru seluas $5.926 \mathrm{~m}$. Perpustakaan UI turut serta dalam mendukung UI menjadi Universitas Riset Kelas Dunia dengan membentuk Sistem Perpustakaan Universitas Indonesia Terpadu (SPUIT). Sistem Perpustakaan Univeristas Indonesia Terpadu ini dikukuhkan dengan Keputusan Rektor 
No.230/SK/R/UI/1999 pada 16 Agustus 1999.

Universitas Indonesia terus memberikan perhatian signifikan kepada perpustakaan sebagai jantung universitas. Hal ini dibuktikan dengan didirikannya sebuah gedung baru perpustakaan pada tahun 2010 dan selesai pada tahun 2011. Pembangunan gedung baru ini dilakukan untuk pengintegrasian seluruh perpustakaan di lingkungan kampus dengan "Crystal of Knowledge" dan dengan bergabungnya perpustakaan fakultas ke gedung baru maka istilah UPT Perpustakaan berubah menjadi Perpustakaan Universitas Indonesia (Perpustakaan UI). Perpustakaan UI yang didesain dengan bentuk bangunan yang megah, nyaman, dan berbagai fasilitas untuk anggotanya. 12

Gedung bernama "Crystal of Knowledge" ini selesai dibangun di awal dan mengalami proses integrasi pada tahun 2011. Adapun perpustakaan yang bergabung ke gedung baru tersebut adalah: Perpustakaan Pusat, Perpustakaan FIB, Perpustakaan FT, Perpustakaan FMIPA, Perpustakaan FIK, Perpustakaan FH; sedangkan beberapa fakultas lain masih tetap memiliki perpustakaan di fakultas namun memindahkan sebagian koleksinya ke gedung baru, yakni: Perpustakaan FASILKOM, Perpustakaan Psikologi, Perpustakaan FISIP, Perpustakaan FKM, dan Perpustakaan FE.

$$
\text { Perpustakaan Universitas }
$$

Indonesia saat ini dipimpin oleh Fuad Gani, S.S., M.A, dengan visi "Menjadi Rujukan Utama Perkembangan Ilmu Pengetahuan Bagi Perpustakaan Perguruan Tinggi Nasional dan Regional"serta secara bersama menggapai misi dalam "Menyediakan akses luas untuk Warga UI dan Publik kesumber daya Informasi dan pengetahuan berkualitas". Kepemimpinan Bapak Fuad Gani, S.S., M.A, membawahi beberepa koordinator yaitu Koordinator Administrasi Umum dan fasilitas dengan Dra. Etty Setyawati M.Hum, membawahi 23 orang pegawai perpustakaan. Koordinator Manajemen Pengetahuan dengan Laely Wahyuli, SS, M.Hum dengan 19 orang pegawai dan Koordinator Layanan Perpustakaan dengan Mariyah, S.Sos, M.Hum., terdiri dari 35 orang pegawai.

Prinsip utama Perpustakaan UI adalah ruang publik yang paling terbuka dan demokratis bagi seluruh warga UI, tempat menggali pengetahuan dan menambang ilmu yang dipancarkan bagi kemanusiaan, serta pendukung utama untuk olah pikir, olah rasa, dan olah raga. Dengan demikian Perpustakaan UI lebih fokus pada pengelolaan aktifitasaktifitas yang mendukung pengembangan kualitas manusia melalui pendidikan dan penelitian, serta penyediaan sarana dan fasilitas sebagai meeting point dan learning common bagi seluruh pemustaka dari berbagai disiplin ilmu.

Perpustakaan Universitas Indonesia saat ini membuka jam layanan dari hari senin sampai jumat pada pukul 08.00-19.00 WIB, khusus untuk ruang internet dan kubikus sampai dengan pukul 21.00 WIB dan sabtu pada pukul 08.00-16.00 WIB. Pencapaian visi dan misi perpustakaan diberikan melalui pengoptimalan layanan perpustakaan.

Menjalankan visi Perpustakaan UI "Menjadi Rujukan Utama Perkembangan Ilmu Pengetahuan bagi Perpustakaan Perguruan Tinggi” dilakukan dengan berbagai macam

\footnotetext{
${ }^{12}$ http://www.lib.ui.ac.id/profil.jsp?hal=3 Perpustakaan Universitas Indonesia. Profil Perpustakaan
} 
pengembangan. Perpustakaan Universitas Indonesia adalah salah satu unit pendukung utama kegiatan akademik (pembelajaran, pengajaran dan penelitian). Perpustakaan UI terus berusaha mengembangkan diri dengan menambah koleksi terbaru, melanggan berbagai online databases, mengembangkan system dan meningkatkan berbagai layanan kepada pemustaka salah satunya melalui pemberian layanan referensi.

Layanan referensi di Perpustakaan UI mulai dirancang pada tahun 2002, dengan fokus layanan diperuntukkan untuk mahasiswa pascasarjana dengan tujuan mengarahkan pemustaka dalam telusur informasi, paket informasi terutama untuk pemustaka yang sedang mengerjakan tugas akhir dan penelitian. Dalam perkembangan layanan, maka tujuan layanan referensi ini sendiri di Perpustakaan UI adalah untuk a) membantu pemustaka (civa UI dan non UI) dalam mendapatkan informasi untuk penelitian, pendidikan dan pengajaran, serta pengabdian masyarakat. b) Mengenalkan fasilitas, layanan dan jenis koleksi Perpustakaan UI. c) Mengenalkan sumber-sumber informasi di dalam dan luar UI.d) Memberikan kemudahan bagi pemustaka dalam mengakses sumber informasi., e) Memanfaatkan secara maksimal sumber-sumber informasi baik dalam bentuk tercetak maupun elektronik dan f) Membantu pemustaka dalam mencari informasi secara efektif dan efisien.

$$
\text { Berbagai perkembangan }
$$

infrastruktur dan layanan Perpustakaan UI dari tahun ke tahun sebagaimana yang telah diungkapkan pada paragraf sebelumnya, membuktikan adanya mitos keberpihakan Perpustakaa UI kepada pemustaka secara historis. Perpustakaan UI menunjukkan kepeduliannya untuk terus mengikuti perkembangan kebutuhan pemustaka, hal ini sematamata dilakukan adalah untuk meningkatkan kualitas layanan perpustakaan dan menjalankan visi dan misi yang telah ditetapkan Perpustakaan UI terutama untuk menjadi Pusat Rujukan secara Regional maupun Internasional.

Pada era informasi seperti ini, umumnya pemustaka memiliki karakteristik yang lebih terbuka wawasannya, lebih mengglobal, tidak dikekang oleh ruang dan waktu, dan terbiasa menghabiskan sebagaian waktunya berselancar didunia maya untuk menelusur dan mencari informasi sesuai dengan keinginan dan seleranya. Hal ini merupakan sebuah tanda terhadap tipe pemustaka yang dapat digunakan untuk menganalisis bagaimana perpustakaan sebaiknya memberikan pelayanan pada pemustaka. Dapat dipastikan, karakteristik pemustaka di era revolusi informasi adalah warga masyarakat yang seringkali disebut sebagai net generation. Perpustakaan dapat menangkap sikap masyarakat yang makin terbiasa berselancar didunia maya dan menginginkan segala informasi dapat diperoleh dengan seketika.

Salah satu upaya perpustakaan ketika memberikan layanan yang luar biasa dalam mencapai tujuan mereka yaitu dengan meningkatkan layanan referensi virtual. Hal ini bertujuan agar dapat membantu pemustaka dalam memenuhi kebutuhan informasi mereka, menegaskan bahwa pustakawan mampu terus mengikuti kebutuhan pemustaka dan memberikn jawaban atas pertanyaan yang hadir baik secara langsunag maupun melalui Media atau Saluran Komunikasi Virtual Layanan Referensi Perpustakaan UI. Berikut penjelasan 
beberapa saluran yang digunakan oleh Perpustakaan UI mengikuti perkembangan layanan.

Berdasarkan hasil penelitian melalui wawancara dengan pustakawan referensi di Perpustakaan UI sebut saja Anggrek, dia menjelaskan bahwa pengembangan layanan referensi dalam bentuk digital telah dilakukan. Hal ini dilakukan karena perkembangan teknologi, kebutuhan mahasiswa (digital age) dan tuntutan akan ketersediaan jurnal online. Berbagai latar belakang di atas pada akhirnya telah merubah akses layanan di perpustakaan baik itu perubahan format sumber informasi, peningkatan akses layanan berbasis teknologi dan sumber daya informasinya yang beralih menjadi virtual termasuk untuk layanan referensi. 13

Pada awal abad 21, pustakawan referensi mulai melayani permintaan informasi melalui telepon dan surat elektronik (e-mail) sehingga layanan untuk membantu pemustaka menjadi lebih mudah karena dapat dilakukan melalui berbagai media komunikasi tanpa bertatap muka secara langsung. Wolfe, Naylor \& Drueke (2010) ${ }^{14}$ mengatakan bahwa sejalan dengan perkembangan teknologi informasi dan komunikasi, layanan referensi mengalami perkembangan dengan memanfaatkan media komunikasi seperti surat elektronik (e-mail), percakapan online (chatting), pesan instan melalui internet (instant message), dan juga pesan teks melalui telepon selular.

Perkembangan penerapan berbagai media komunikasi pada layanan referensi virtual di Perpustakaan UI ini

\footnotetext{
13 Wawancara dengan dua pustakawan yang bertugas pada layanan referensi virtual

${ }^{14}$ Wolfe, Judith A.; Naylor, Ted; and Drueke, Jeanetta, "The Role of the Academic Reference Librarian in the Learning Commons" (2010). Faculty Publications, UNL Libraries. 221
}

mengalami proses yang panjang, yang awal penerapannya terus meningkat karena beberapa faktor kemudian perlahan menurun. Pustakawan yang bertugas juga mengungkapkan bahwa dalam mengaplikasikan saluran yang ada terkadang mereka juga mengalami beberapa kendala, dari mulai awal penggunaan media yanag telah disediakan sampai sekarang. Layanan konsultasi referensi secara personal di perpustakaan UI ternyata secara aktif masih menggunakan saluran melalui sms, email, whatsapp dan twitter dari akun perpustakaan.

Hal serupa juga diutarakan oleh Kolthuri, K. Kiran (2014) ${ }^{15}$ dalam tulisannya menjelaskan bahwa sarana yang dapat digunakan dalam penyediaan layanan referensi virtual adalah:

a. Chat; Instant messaging (IM); layanan yang digunakan oleh beberapa perpustakaan sebagai sarana yang memudahkan pengguna bebas berkomunikasi secara personal dengan pustakawan. Memanfaatkan IM untuk layanan referensi memungkinkan pengguna untuk menghubungi perpustakaan dari lokasi manapun melalui internet. Layanan ini seperti wawancara referensi tradisional karena merupakan interaksi langsung antara pengguna dan pustakawan.

b. Skype; Voice Over Internet Protocol (VoIP); alat komunikasi yang dapat digunakan untuk melakukan audio atau audio/video "telepon" Memanfaatkan akses komputer

\footnotetext{
15 Nagar, kisan. "an overview of virtual reference tools, technologiesand services in libraries," (2014), 5.
} 
dan jaringan internet dengan menggunakan software sehingga layanan ini dapat dilakukan dengan mudah.

c. Twitter; Twitter adalah layanan micro-blogging gratis yang memungkinkan penggunanya untuk mengirim dan membaca text pesan berbasis hingga 140 karakter yang dikenal sebagai "tweets" melalui situs twitter. Menggunakan twitter terus diberdayakan sebagai komunikasi dan menjadi penghubung antara pustakawan dan masyarakat.

d. Mosio; Teks komersial berbasis messaging dan email yang tersedia saat chatting dimatikan. Integrasi dengan facebook, beberapa lapisan pencarian informasi, OPACs, dan database online lainnya. Media ini membuat pengguna lebih dapat mencari referensi sesuai dengan kebutuhan.

Pengoptimalan layanan referensi di Pepustakaan UI ini sebetulnya sudah dilaksanakan dari semenjak perpustakaan di gedung lama. Melati salah seorang pustakawan yang bertugas mengatakan bahwa awalnya sebelum internet ada layanan ini sudah menyediakan akses secara virtual melalui Short Message Service. Perkembangan teknologi informasi dan komunikasi ikut mempengaruhi pergeseran bentuk layanan, dari saluran SMS bergeser ke satu email perpustakaan sebelum akhirnya dipisah per- layanan (e-mail refdesk) dan sampai setelah pindah ke gedung baru perpustakaan menyediakannya media/saluran secara tersistem dengan menyambungkannya melalui aplikasi
Lontar

Perpustakaan

http://lontar.ui.ac.id seperti Frequeently Asked Question (FAQ), Ask Librarian, Request Library Information dan.email layanan referensi (refdesk.lib@ui.ac.id) 16 .

\section{Frequeently Asked Question (FAQ)}

FAQ adalah singkatan dari Frequently , Asked \& Question merupakan sebuah alat bantu bagi siapa saja yang ingin mengetahui, menanyakan suatu hal yang tidak kita ketahui dalam website ataupun aplikasi software lainnya. Perpustakaan UI menyediakan wadah bagi pemustaka dan pustakawan untuk bisa saling berinteraksi melalui dunia maya. Perntanyaan yang muncul melalui saluran ini biasanya adalah pertanyaan singkat yang bisa dijawab langsung secara singkat, padat dan jelas. Pemustaka melalui situs http://lontar.ui.ac.id bisa mencari tombol "FAQ" tersebut. Biasanya menu "FAQ" tersebut terdapat pada bagian menu pada website atau pada bagian pengaturan pada aplikasi.

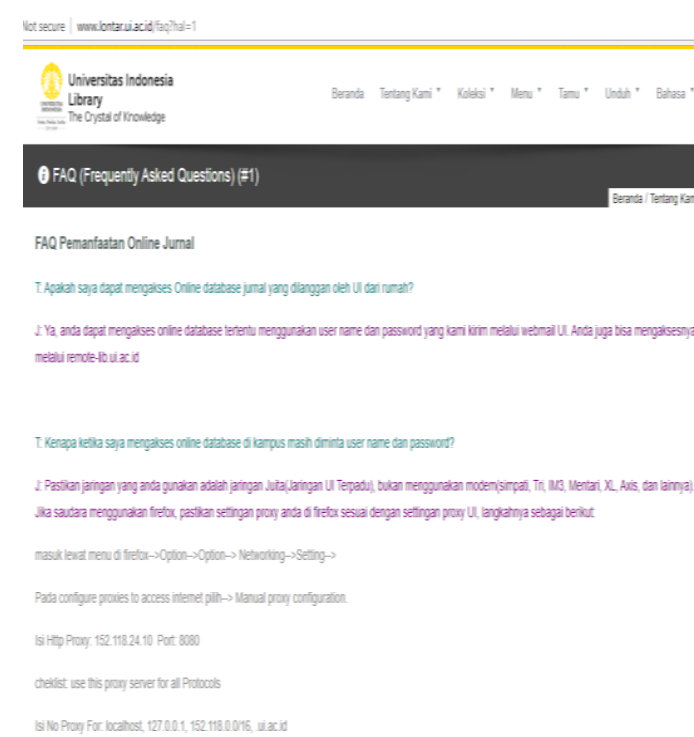

Selain itu, berbagai pertanyaan umum yang telah diinformasikan

16 http://www.lib.ui.ac.id 
jawabnnya juga ditawarkan perpustakaan UI dalam bentuk lain melaluiFAQ (Frequently Ask Question). FAQ adalah merupakan salah satu bentuk kegiatan layanan referensi yang diberikan kepada pemustaka. Sebagai upaya untuk menyediakan informasi kepada pemustaka kapan saja dan dimana saja. Pemustaka data dapat melakukan akses ke informasi seputar perpustakaan, terutama dalam mengatasi hambatan umum, menjawab pertanyaan yang sering diajukan, memudahkan pustakawan untuk mengidentifikasi pertanyaan umum yang belum terjawab oleh pemustaka (Dworak \& Moore, 2015; Stevens, 2013). ${ }^{17}$

\section{Ask Librarian}

Ask Librian sebetulnya merupakan sarana yang disediakan oleh perpustakaan untuk menangkap pertanyaan yang datang dari pemustaka. Ask librarian secara teknis menyediakan bentuk layanan referensi secara virtual. Pemustaka dapat berkomunikasi melalui database interaktif untuk menanyakan informasi yang mereka butuhkan dan menerima respon selanjutnya dari pustakawan. Menerima masukan yang diberikan pemustaka untuk lebih meningatkan layanan peprustakaan dan wadah pustakawan untuk menjawab pertanyaan yang diterima.
17 Dworak, E., \& Moore, C. Connecting questions with answers. In C. Forbes \& J. Bowers (Eds.), Rethinking reference for

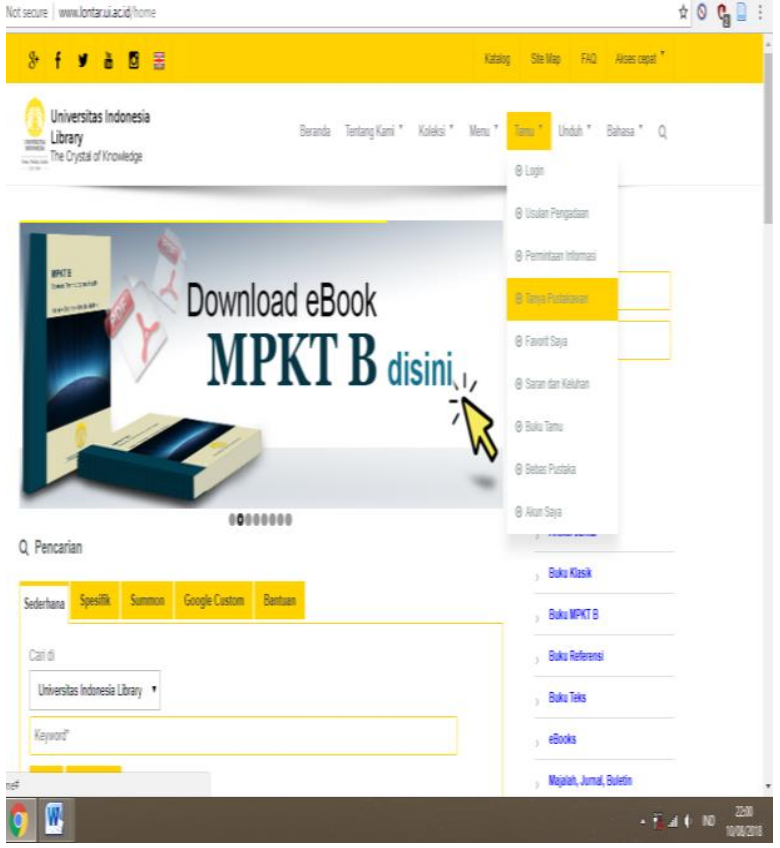

Konsep layanan referensi elektronik yang dijalankan oleh perpustakaan UI juga dihadirkan melalui laman website perpustakaan UI. Melalui website ini perpustakaan dapat menjangkau pemustaka dari ruang yang luas dan pemustaka dapat memaksimalkan penggunaan sumber daya informasi yang ada di perpustakaan tanpa harus datang ke perpustakaan. Salah seorang pustakawan Raflesia menyatakan bahwa melalui halaman website pemustaka dapat menanyakan kebutuhan informasi mereka, dan merujuk ke emailrefdesk yang tertera di halaman website perpustakaan. Halaman web menjadi akses point dalam mengenalkan perpustakaan. Terutama mengenal layanan referensi sebagai ujung tombak layanan perpustakaan UI saat ini.

Website perpustakaan diperlukan salah satunya untuk memasarkan dan mempublikasikan layanan peprustakaan dan sumber daya informasi yang ada di Perpustakaan. Melalui website

academic libraries: Innovative developments and future trends (2015). pp. 99-113. Lanham, MD: Rowman \& Littlefield. 
perpustakaan yang dapat diakses dari http://lib.ui.ac.id. Pemustaka dapat terhubung pada berbagai akses layanan referensi, satu pintu untuk berbagai sumber daya informasi elektronik yang tersedia dan dilanggan oleh perpustakaan. Untuk layanan referensi sendiri pemustaka dapat mengajukan pertanyaan melalui "Ask Librarian" dan " $F A Q$ " untuk mendapatkan respon dari kebutuhan informasi yang ditanyakan. Namun, berbeda halnya ketika layanan ini diterapkan di lapangan.

Raflesia dan Kemuning sebagai pustakawan yang bertugas mengungkapkan secara jelas bahwa ask librarian sebagai sarana komunikasi antara pemustaka dan pustakawan saat secara virtual. Menurut pustakawan yang bertugas bahwa ternyata respon pemustaka dalam memberikan pertanyaan cukup tinggi. Tentunya dengan harapan agar pertanyaan informasi mereka segara mendapat repon yang cepat dari perpustakaan. Dari jawaban di atas pustakawan berasumsi bahwa ask librarian hampir menyerupai library chat layanan referensi. Karena melalui saluran ini terjalin komunikasi aktif secara virtual dalam pemenuhan kebutuhan informasi pemustaka.

Library chatting merupakan jenis layanan yang akan diterapkan juga oleh Perpustakaan UI layanan referensi dan dalam tahap pengembangan. Library chatting merupakan model layanan synchronous dalam menyediakan akses bagi pemustaka untuk menyampaikan kebutuhan informasi mereka dalam realtime. Chatting yang dapat dilakukan pemustaka melalui internet dalam berkomunikasi dengan pustakawan referensi melalui pesang singkat secara real-time. Dengan jendala terpisah yang muncul pada layar komputer untuk mengirim pesan tertulis antara pemustaka dan pustakawan.
Layanan referensi virtual asynchronous adalah model layanan yang ditandai dengan komunikasi satu arah pada satu waktu. Saluran komunikasi yang tersedia seperti e-mail, web form atau Ask a Service, Virtual Reference Desk, Question Point, Online Pathfinders, dan sejenisnya. Saluran ini dapat digunakan pemustaka untuk menanyakan tentang kebutuhan informasinya kepada pustakawan (Sharma, Kumar and Singh, 2005:983).

Pemustaka dapat mengajukan berbagai pertanyaan melalui chatting ini, dan pustakawan langsung dapat memberikan jawaban yang diajukan. Membantu pemustaka menemukan informasi melaluilink ke sumber informasi yang diinginkan. Layanan library chat ini adalah merupakah salah satu pilihan alami, apalagi ketika pemustaka sangat membutuhkan jawaban dari kebutuhan informasi mereka dengan segera. Pustakawan merujuk pemustaka memanfaatkan sumberinformasi elektronik yang ada di perpustakaan dan sumber informasi yang tersedia secara elektronik dari internet.

\section{Email Layanan Referensi}

Perkembangan

TIK

mempengaruhi pemberian layanan referensi, perpustakaan memanfaatkan kemudahan yang diberikan oleh teknologi dalam meningkatkan layanan referensi. Hal ini ditandai dengan pemberian layanan referensi di Perpustakaan UI diberikan menggunakan saluran elektronik. Saat sekarang ini telah dilakukan menggunakan media komunikasi email melalui alamat refdesk.lib@ui.ac.id. Layanan referensi di Perpustakaan UI menggunakan email sebagai tools merupakan perkembangan layanan setelah hadirnya teknologi informasi dan internet. Perkembangan layanan referensi secara elektronik ini juga sudah 
dijelaskan oleh Boop dan Smith (2001) bahwa pada abad 21 dimana pustakawan referensi akan melayani permintaan informasi menggunakan media komunikasi baik melalui telepon dan surat elektronik (e-mail) tanpa bertemu secara langsung dan akses dilayankan secara virtual.

\section{Menurut Machine Assisted}

Reference Section (MARS) dalam Pedoman penyelenggaran Layanan Referensi Virtual oleh RUSA, 2010 menyatakan bahwa: Layanan referensi virtual dimulai secara elektronik dimana pengguna menggunakan komputer atau teknologi internet lainnya untuk berkomunikasi dengan pustakawan, tanpa hadir secara fisik ke Perpustakaan. Saluran/Media komunikasi yang sering digunakan dalam referensi virtual termasuk chatting video conference, Voice over $I P$, e-mail dan pesan instan. Query Referensi Virtual sering ditindak lanjuti melalui telepon, fax, dan e-mail biasa, bahkan meskipun model komunikasi ini tidak dianggap virtual. E-mail merupakan media efektif yang dapat digunakan dalam berkomunikasi jarak jauh secara virtual dalam layanan referensi. Ketika pemustaka memiliki pertanyaan lebih dalam dan pustakawan juga membutuhkan saluran untuk pencarian ekstensif dari sumber informasi yang mereka butuhkan. Permintaan informasi melalui email yang biasanya diterima dari pemustaka adalah seperti permintaan berupa akan pencarian literatur. Setelah itu, pustakawan akan segera mengirimkan umpan balik jika artikel yang dimaksudkan sudah ditemukan.

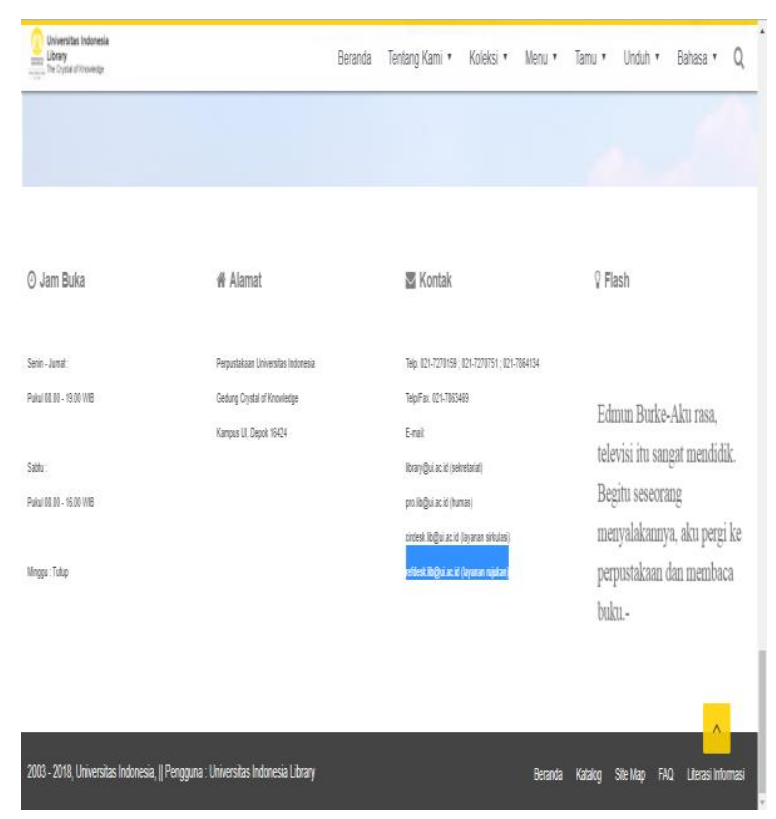

Layanan referensi elektronik yang hadir melalui sarana komunikasi email adalah salah satu bukti hadirnya sarana komunikasi virtual dalam layanan referensi. Ketergunaanya dalam layanan referensi virtual di Perpustakaan UI diupayakan hadir lebih dari sekadar saluran untuk mengirimkan literatur saja. Melalui email ini pemberian layanan referensi justru dapat hadir untuk lebih mendekatkan diri dengan pengguna melalui pengiriman literatur sesuai dengan peminatan pemustaka secara aktif. Hal inilah yang sekarang mulai diterapkan pada layanan referensi di Perpustalaan UI. Layanan yang diberikan menggunakan email sebagai sarana komunikasi aktif adalah dengan menghadirkan kegiatan baru bernama EDS "Eelectronic delivery Services". Kegiatan layanan referensi yang menyediakan layanan pengiriman dokumen elektronik untuk pemustaka UI yang berada di luar kampus. Ini merupakan perkembangan konsep baru dari layanan referensi elektronik yang menggunakan email menjadi saluran aktif dalam pengiriman dokumen.

Berdasarkan wawancara beberapa Informan menjelaskan pandangan mereka bahwa EDS merupakan kegiatan 
layanan yang memberikan gaya baru dalam menyediakan akses yang lebih mudah. Layanan EDS ditawarkan kepada pemustaka civita akademika yang sulit untuk meluangkan waktu datang ke perpustakaan, seperti guru besar, dosen dan staf pengajar. Ini merupakan wajah baru dari layanan referensi yang mulai berjalan di awal tahun 2016. Mengenalkan layanan referensi melalui pengiriman literaturliteratur terbaru kepada mereka, memberikan peluang yang lebih besar bagi perpustakaan untuk menjangkau pemustaka dengan inovasi baru. Pustakawan referensi memiliki tanggung jawab baru mempromosikan layanan referensi dengan cara yang berbeda. Pertumbuhan informasi dalam jumlah yang cukup besar mulai mempengaruhi perpustakaan dalam menyebarkan sumber daya informasinya. Perubahan konsep layanan referensi Perpustakaan UI yang hadir lebih ke refer to deliver turut mengubah cara Perpustakaan UI dan pandangan pustakawan dalam mengenalkan layanan referensi kepada pemustaka, salah satunya dengan layanan EDS melalui email eds.lib@ui.ac.id.

Menawarkan sumber daya elektronik kepada beberapa kelompok pemustaka memang merupakan inovasi baru dalam meningkatkan pemanfaatan layanan referensi.. Memilih koleksi yang diseuaikan dengan latar belakang pemustaka bukanlah hal yang mudah untuk diterapkan. Diperlukan keahlian khusus bagi pustakawan untuk lebih mengenal berbagai subjek penelusuran informasi dalam mendapatkan artikel akurat yang akan dikirimkan kepada pemustaka. Merupakan salah satu jenis layanan referensi yang menuntut ketapatan dan keakuratan dalam penyeleksian, yang kita kenal dengan

18 Bopp, Richard E., \& Smith, Linda C. Reference and Information Services: an istilah selective dissemination of information.Selective dissemination of information menyediakan layanan informasi terpilih yang diolah dan disajikan kepada pemustaka sesuai dengan bidang ilmu atau minat mereka (Bunge dan Bopp: 2001, 6). ${ }^{18}$

Penelusuran informasi menggunakan subjek yang beragam membutuhkan pengetahuan pustakawan yang luas. Oleh karena itu pustakawan referensi yang bertugas menyadari bahwa mereka memerlukan dukungan perpustakaan UI untuk memberikan mereka pelatihan khusus. Hal ini bertujuan untuk memperdalam pengetahuan pustakawan mengenai subjek keilmuwan sesuai bagian yang telah ditetapkan. Kendala ini wajar terjadi karena jika bentuk pemberian layanan EDS bertujuan untuk menawarkan artikel update kepada pemustaka yang disesuaikan dengan peminatannya. Penulis melihat dari jawaban yang diberikan oleh informan yang bertugas, pustakawan referensi mengalami kesulitan yang harus diatasi sesegara mungkin oleh Perpustakaan UI.

Penting untuk setiap pustakawan referensi untuk meningkatkan pengetahuannya, karna pengetahuan merupakan salah satu kompetensi dasar yang harus dimiliki oleh pustakawan referensi sebagaimana yang dijelaskan oleh RUSA. Pengetahuan dasar; maksudnya adalah kesadaran pustakawan dalam mengikuti penerapan dan konsep baru dalam lingkungan perpustakaan (RUSA,2006).

Jawaban Informan menunjukkan bahwa Perpustakaan UI terus melakukan perkembangan layanan perpustakaan terutama untuk layanan referensi secara virtual. Menyediakan media komunikasi virtual berbasis email, adalah salah satu

introduction. (3rd ed.). (Englewood, Colorado: Libraries Unlimited. 2001) 
usaha yang baik untuk berkomunikasi dengan pemustaka melalui dunia maya.

Arya, B. Harsh dan Mishra J.K $(2012)^{19}$ menyatakan bahwa layanan email menjadi layanan popular hingga saat sekarang ini, baik itu bagi pustakawan dan pengguna. Adapun keuntungannya adalah:

- pemustaka tidak memerlukan software tambahan dan pertanyaan dapat disampaikan secara bebas (interpersonal) dengan gaya bahasa sendiri.

- e-mail paling mudah untuk diterapkan di perpustakaan dan pustakawaan harusnya tidak memerlukan pelatihan khusus dalam menggunakannya

- pustakawan referensi menemukan lebih banyak waktu untuk berpikir, merencanakan strategi, mencari dan memberikan jawabannya.

- tidak ada pembatasan waktu kerja dan pengguna dapat meminta permintaan setiap saat.

Perkembangan media komunikasi yang hadir, mulai membuat penggunaan e-mail dirasa kurang optimal terumata setelah kehadiran videocall atau skype. Adapun kekurangannya adalah:

- tidak mungkin digunakan sebagai interaksi tatap muka, referensi pustakawan tidak bisa mendapatkan klarifikasi tentang keraguannya yang timbul dalam benaknya setelah menerima query.

- Kecepatan menerima dan menjawab pertanyaan tergantung pada volume lalu lintas $e$-mail dan komunikasi yang menghubungkannya melalui internet.

\footnotetext{
${ }^{19}$ Arya, Harsh Bardhan., Mishra, J. KVirtual Reference Services: Tools and Techniques. International Research: Journal of Library \& Information Science. . (2012) . 2(1), 102- 115
}

- Sulit untuk pustakawan referensi dalam menilai urgensi informasi.

Bahkan pengaruh perkembangan kecanggihan teknologi sampai pada hubungan layanan yang lebih pribadi melalui aplikasi WhatsApp.

Layanan referensi virtual kemudian menuntut para pustakawan untuk mampu mengoperasikan teknologi informasi dengan baik. Jika melihat pada hasil wawancara ternyata latar belakang kegemaran, umur dan interaksi dengan teknologi sangat berpengaruh bagi beberapa pustakawan. Kemudian bagi beberapa pustakawan layanan referensi virtual yang tergolong dalam golongan digital immigrant, mereka merasa masih membutuhkan adaptasi terhadap perkembangan teknologi.

Pustakawan Referensi pada hakikatnya hadir untuk menjawab kebutuhan pengguna dalam mempraktekkan apa yang diharapkan atau dijabarkan oleh ranganathan, diantara fungsi pustakawan referensi adalah: Fungsi pustakawan rujukan ada 4 fungsi, yaitu:

1. Menginstruksikan kepada pengguna bagaimana menggunakan perpustakaan.

2. Menjawab permintaan atau pertanyaan pengguna.

3. Membantu pengguna memilih sumber- sumber informasi. Fungsi ini merupakan hubungan antara pengetahuan yang dimiliki pustakawan mengenai koleksi dengan kebutuhan dari pengguna.

4. Mempromosikan perpustakaan kepada komunitas penggunanya. (Green dalam Tyckoson, 2007: $104)^{20}$

${ }^{20}$ Tyckoson, Davida. What Is the Best Model of Reference Service? . (University of Illinois: The Board of Trustees. 2007). 
Pemberian layanan EDS merupakan langkah yang signifikan dalam pengembangan konsep layanan referensi elektronik, melalui kegiatan ini perpustakaan memberikan kesempatan kepada pendidik akademisi dalam memanfaatkan sumber daya informasi elektronik yang ada di Perpustakaan. Layanan EDS ke depan agar dapat menjadi salah satu program unggulan layanan referensi Perpustakaan UI. Secara umum dapat dimaknai bahwa harapan beberapa informan agar jumlah pustakawan yang dilibatkan dalam layanan ini agar ditambah dan sebanding dengan jumlah kelompok pemustaka yang akan dilayani. Hal ini dimaksudkan agar pemberikan artikel dapat berjalan efektif dan merata didapatkan oleh pemustaka. Disamping itu pustakawan menginginkan diberikan data lengkap latar belakang pemustaka, agar penelusuran dan pengiriman artikel terbaru tepat sesuai dengan keilmuwan para guru besar ini. Mengirimkan artikel terbaru sesuai dengan keilmuwan akademisi sebagai kelompok pemustaka menurut Perpustakaan UI merupakan cara baru. Layanan ini diharapkan nantinya agar akademisi lebih mengetahui keberdaan layanan referensi dengan berbagai sumber informasi up dateyang dapat mendukung proses pembelajaran dan penelitian.

Pustakawan memandang bahwa EDS merupakan bentuk pemberian layanan referensi baru yang sedang hangat dan gencar-gencarnya diterapkan dalam layanan referensi Perpustakaan UI. Senjata baru dalam menarik minat kelompok pemustaka dari kalangan akademisi. Sumber daya informasi yang menjadi unsur utama dalam layanan ini juga menjadi perhatian penting bagi perpustakaan. Pengembangannya perlu terus ditingkatkan terutama untuk langgan online database yang disesuaikan dengan kebutuhan pemustaka. Tingginya antusiasme dari pustakawan layanan referemsi untuk berperan aktif dalam layanan baru ini, namun sisi lain berakibat pada beban kerja yang membuat pustakawan kewalahan karena keterbatasan tenaga. Perpustakaan melalui layanan referensi memberikan cara yang berbeda, mendekatkan diri dengan pemustaka dengan menawarakan artikel terbaru melalui layanan ini.

Inovasi baru layanan referensi ini tetap bertujuan agar sumber daya informasi elektronik yang ada di Perpustakaan lebih bermanfaat dan digunakan oleh pemustaka khususnya akademisi yang susah untuk datang ke Perpustakaan. Kelompok pemustaka akademisi diberikan kesempatan yang sama untuk lebih mengenal dan memanfaatkan sumber daya informasi yang ada di Perpustakaan.

\section{Kesimpulan}

Melalui ketersediaan layanan referensi virtual ini maka perpustakaan dapat memperluas layanan kepada komunitas pengguna tanpa dibatasi ruang dan waktu. Transformasi layanan ini dilakukan semata-mata demi memudahkan pengguna dalam menelusur informasi yang mereka butuhkan, beliau menjelaskan bahwa dari awal pengembangan layanan ini diberikan hingga sekarang kami dari pustakawan selalu mengutamakan job dask sebagai pustakawan referensi seperti melayani pengguna, mengajak civitas akademik untuk memahami cara penelesuran e-journal di ruangan dan mengadakan kegiatan literasi informasi.

Perpustakaan perlu mempertimbangkan penerapakan media teknologi berbasis chat yang terhubungan dengan halaman web Perpustakaan. Hal ini bertujuan untuk 
dapat menjangkau pemustaka tanpa batas dari jarak jauh dan berkomunikasi dengan pustakawaan referensi secara real time. Apalagi jika melihat pada latar belakang pemustaka yang sudah akrab menggunakan media teknologi dalam keseharian mereka. Tidak dapat dipungkiri bahwa media teknologi memiliki potensi sebagai langkah awal dalam berkomunikasi dengan pemustaka dari manapun mereka berada. Adanya link-link yang dihubungkan dari halaman web perpustakaan dan ruang chat adalah pintu untuk menghubungkan pemustaka dengan pustakawan referensi. Pemustaka dapat diberikan salinan percakapan yang terjadi setelah proses chat selesai. Salinan percakapan tersebut juga dapat digunakan sebagai arsip database untuk informasi statistik layananan referensi seperti jumlah chat, durasi chat, topic yang dibahas, lokasi pemustaka dan lain sebagainya. Teknologi yang diterapkan dalam layanan referensi elektronik bisa lebih dikenalkan melalui halaman web ini, halaman web juga bisa lebih berkembang dengan menampilkan tutorial sederhana dan menjawab pertanyaan sederhana mengenai pedoman penggunaan software, media komunikasi dan toolsyang disedakan Perpustakaan terutama dalam penelusuran informasi.

Pengembangan layanan untuk dunia virtual menjadi hal penting bagi perpustakaan dalam menjalin hubungan baik dengan pengguna. Layanan referensi virtual menjadi salah satu layanan yang sedang hangat dieksplorasi sekarang dalam mendukung kebutuhan pengguna baik dosen, staff dan mahasiswa dalam memenuhi kebutuhan sumber daya virtual library. Referensi virtual memiliki potensi yang sangat besar untuk merevolusi cara pengguna menemukan dan menggunakan layanan referensi. Layanan ini diberikan dengan menambahkan bantuan interaktif untuk layanan informasi online bagi pengguna dan pustakawan dapat menjangkau pengguna yang mungkin tidak dapat langsung datang ke perpustakaan dikarenakan jarak dan waktu. Merupakan misi pustakawan adalah untuk membangun sebuah koleksi yang terorganisir dengan baik, bertujuan untuk memaksimalkan kesempatan bahwa pengguna akan menemukan sumber informasi yang mereka butuhkan. Pada intinya bahwa tugas pustakawan adalah untuk membantu agar orang-orang yang datang menemukan sumber daya yang mereka cari.

\section{DAFTAR PUSTAKA}

\section{BUKU}

Arikunto, Suharsimi. Ed. Rev VI. Cet. Ketigabelas. Prosedur Penelitian:suatu pendekatan praktek. Jakarta: Rineka Cipta. 2006.

Bopp, Richard E., \& Smith, Linda C. Reference and Information Services:an introduction. (3rd ed.). Englewood, Colorado: Libraries Unlimited. 2001.

Bungin, Burhan. Metode Penelitian Kuantitatif. Jakarta: Kencana. 2008.

Kriyantono, rachmat. Teknik Praktis Riset Komunikasi. Jakarta: Kencana. 2007.

Kern, Kathleen M. Virtual Reference Best Practice; tailoring service to your library. United States of America: American Library Association. 2009. 
Sugiyono. Memahami Penelitian Kualitatif, Bandung: Alfabeta. 2005.

Sugiyono. Metode Penelitian Kuantitatif, Kualitatif, dan Kombinasi (Mixed Methods).Bandung: Alfabeta. 2012.

Tyckoson, Davida. What Is the Best Model of Reference Service?. University of Illinois: The Board of Trustees.

\section{ARTIKEL}

Berube, L. Digital reference overview.(An issue paper from the Networked Services Policy Task Group). 2003. Retrieved http://www.ukoln.ac.uk/public/n sptg/virtual/

Cloonan, M. V., \& Dove, J. G. Ranganathan online: Do digital libraries violate the Third Law Library Journal, (2005) 130(6), $58-60$.

Conway, Lynn Silipigni and Faniel, Ixchel M. Reordering Ranganathan: Shifting User Behaviors, Shifting Priorities. Dublin Ohio USA: OCLC Online Computer Library Center, Inc. 2014

Dollah, W. K. W., \& Singh, D.Digital reference services in academic libraries. 2002. Retrieved http://www.ipl.org/div/papers/sy mposium 2002/systems.html.

Hoye, David.Wired Life: Use of public libraries grows with Internet. 2002 Retrieval at http://www.sacbee.com/contentb usiness/story/4460123p5480900 c.html.

Maharana, B. and Panda, K. C. Virtual Reference Service in Academic Libraries: A Case Study of the Libraries of IIMs and IITs in India. 2005. Availabe at http://eprints.rclis.org/9358/

New Jersey Library Association. Reference and Information Services Competencies. 2002 Availabe at http://www.njla.org/resources/re fincomp.html

Nicholas, P. Creating a digital reference agenda for academic libraries in Jamaica: An exploratory case study. Libri, 2012. 61, 258-280. doi:10.1515/libr.2011.023

Pomerantz, J., Nicholson, S., Belanger, Y. \& Lankes. R. D. The current state of digital reference: Validation of a general digital reference model through a survey of digital reference services. Information Processing and Management, 2004 40, 347363.doi:10.1016/S03064573(02)00085-7

Schachaf, P., \& Horowitz, S. H. Virtual reference service evaluation: Adherence to RUSA behavioural guidelines and IFLA digital reference guidelines.Library and Information Science Research. 2008

\section{WEB}

Shidarta. "The Reasoned Actioned

Theory," http://dartaanekateori.blogspot.com (di akses tgl. 19 Februari 2018) 
Media Komunikasi Sebagai Akses Layanan Referensi Virtual di Perpustakaan Universitas Indonesia

\section{Universitas Indonesia "Tentang \\ Perpustakaan Universitas}

Indonesia"

http://www.lib.ui.ac.id/ (diakses

pada tanggal 26 agustus 2018). 